\title{
Toward a Framework for Systemic Liquidity Policy
}

Claudia Dziobek, J. Kim Hobbs, and

David Marston 


\title{
IMF Working Paper
}

Monetary and Exchange Affairs Department

\section{Toward a Framework for Systemic Liquidity Policy}

\author{
Prepared by Claudia Dziobek, J. Kim Hobbs, and David Marston ${ }^{1}$ \\ Authorized for distribution by William E. Alexander
}

March 2000

\begin{abstract}
The views expressed in this Working Paper are those of the author(s) and do not necessarily represent those of the IMF or IMF policy. Working Papers describe research in progress by the author(s) and are published to elicit comments and to further debate.
\end{abstract}

International policy efforts to strengthen financial systems have highlighted the role of liquidity. This paper explores a framework to assess arrangements for market liquidity and lays out elements of systemic liquidity policy. Robust arrangements for liquidity provide confidence to market participants that liquidity can be mobilized on demand in a predictable and transparent manner. These are crucial to resilience and effective monetary operations. Arrangements include several prudential and institutional elements and national authorities have an important role in promoting their adoption. A survey of 14 countries and two in-depth studies of Mexico and Argentina are included for illustration.

\section{JEL Classification Numbers:E42, E44}

Keywords: Financial architecture, liquidity management, creditor rights, microstructure Author's E-Mail Address: cdziobek@imf.org, dmarston@imf.org

\footnotetext{
${ }^{1} \mathrm{Mr}$. Hobbs is an independent consultant and former commercial bank treasurer. The authors would like to thank William E. Alexander and V. Sundararajan for initiating the research project and providing valuable comments. This draft has also benefited from comments by staff of the Central Bank of Argentina and the Central Bank of Mexico, and by Edward Frydl, Eliot Kalter, Meral Karasulu, Elisabeth Milne, Gabriel Sensenbrenner, Mark Swinburne, Bob Traa, and other colleagues during an MAE seminar. Research assistance was provided by Jahanara Begum and Anil Bhatia.
} 


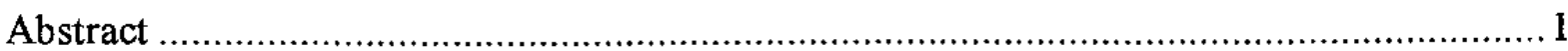

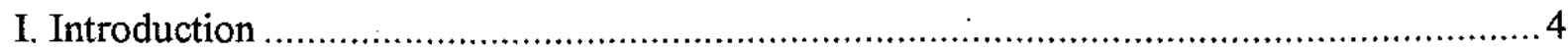

II. Bank Portfolio Considerations in Liquidity Operations ...................................... 5

A. Issues in Volatility and Resilience.......................................................... 5

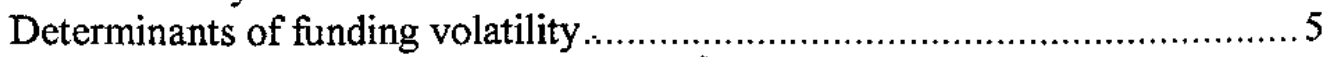

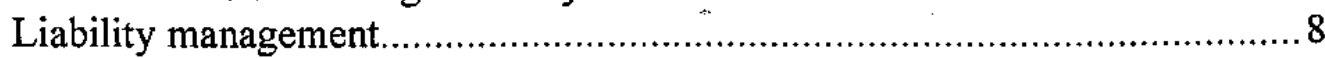

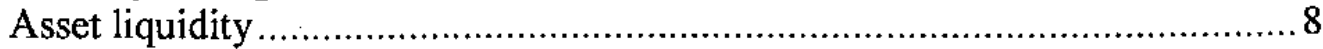

B. Measuring Funding Volatility-An Aggregate Balance Sheet Approach ..............9

III. Infrastructure for Short-Term Liquidity Management .......................................... 11

A. Day-to-Day Liquidity Management Support .......................................... 11

Market framework issues affecting liquidity ...................................... 12

Monetary instrument design affecting liquidity.................................. 14

Payment system arrangements...................................................... 16

Foreign exchange liquidity ......................................................... 16

B. Safety-Net Infrastructure ................................................................... 18

C. The Importance of a Balanced Liquidity Infrastructure.............................. 19

IV. Systemic Liquidity Framework: Stylized Application........................................ 19

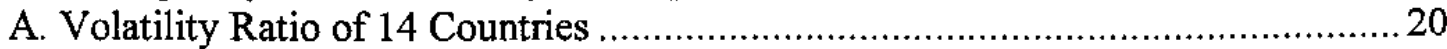

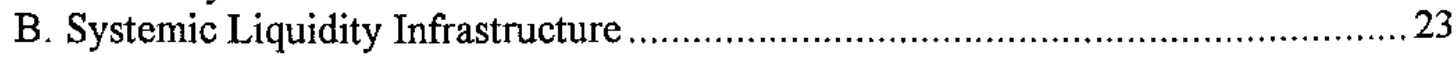

C. Summarizing Information on Systemic Liquidity Frameworks ........................ 24

V. Systemic Liquidity Framework: Case Study Application ........................................26

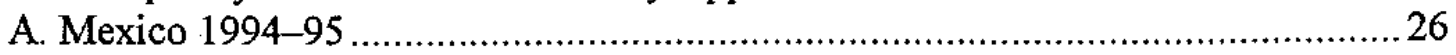

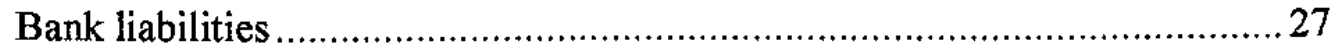

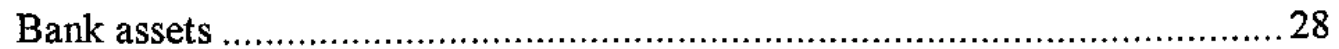

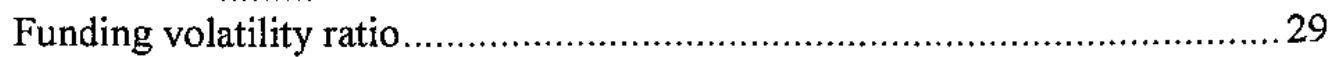

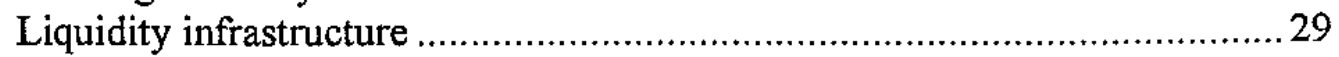

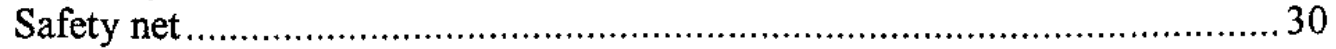

Crisis and response

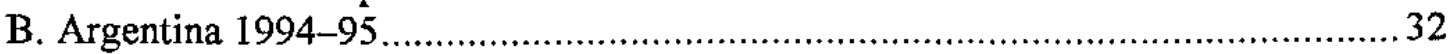

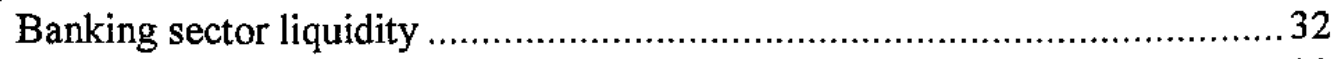

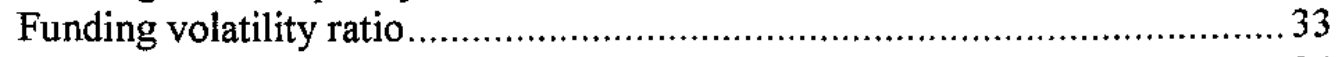

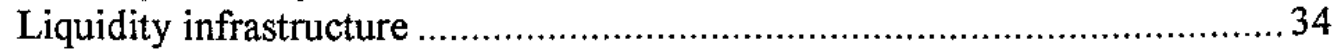

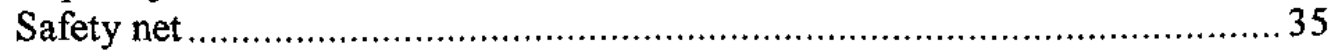

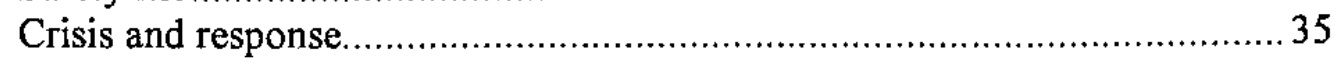

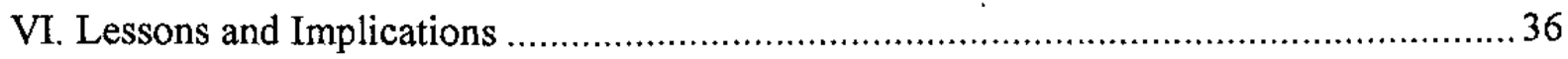


Boxes

Box 1. The Liquidity of Pledgeable Assets .......................................................... 7

Box 2. Should local and foreign currency liquidity be analyzed separately ?.................... 17

Figures

Figure 1. Funding Volatility Concepts Focus on the Gap Between Liquid Assets

Figure 2. Average Highest, and Lowest Values of Volatility Ratios for Selected Countries . 22

Text Tables

Table 1. Interpreting the Funding Volatility Ratio (VL-LA)/(TA-LA) .......................... 10

Table 2. Components of a Balanced Liquidity Infrastructure ....................................... 12

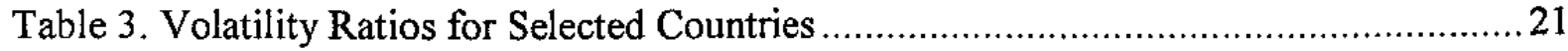

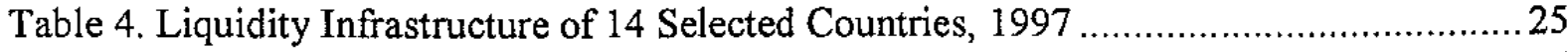

Table 5. Classifying Systemic Liquidity Environments...............................................26

Table 6. Mexico: Commercial Banks Liabilities (Percent of Total Assets) ...................... 27

Table 7. Mexico: Commercial Banks Assets (Percent of Total Assets) ........................... 28

Table 8: Mexico: Systemic Liquidity Infrastructure in 1994 ............................................. 30

Table 9. Argentina: Commercial Banks Balance Sheets (Percent of Total Assets) ...............33

Table 10. Argentina: Systemic Liquidity Infrastructure in 1994 ................................... 34

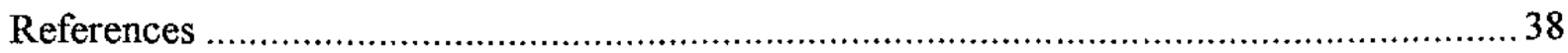




\section{INTRODUCTION}

The capacity for banks to access liquid funding markets and their use of effective liquidity management techniques are important aspects of financial intermediation in that they contribute to financial sector resilience. Without ready access to funding, market participants would be severely constrained in managing payments, transforming maturities, and managing interest rate risk, thus undermining prudent intermediation. Where foreign currency transactions are significant, liquidity management can be complicated by the ease with which funds can be converted from one currency to another, which is linked to the credibility of the exchange rate regime.

An environment permitting sound liquidity management is also essential for effective monetary policy implementation. Where markets are liquid and deep, price discovery and determination will be more efficient, thereby improving the information content of market yields to guide monetary operations. These markets also facilitate effective transmission of central bank intervention from the initial market subset to broader financial markets without undue price volatility. The adequacy of procedures for smooth liquidity management operations are often tested in periods of stress. Under such conditions, rigidities or poorly specified arrangements can have adverse implications for the payment system and bank soundness.

The importance of liquidity for sound banking practice is well established at both the theoretical and operational levels. Market microstructure theory has long focused on liquidity issues in equity and securities markets, but there is also a growing body of academic and empirical literature concerning the importance of money market liquidity, although many of these studies focus on industrial countries, where bank liquidity management takes place against the background of a developed infrastructure which is, therefore, not explicitly spelled out. ${ }^{2}$ In part, renewed interest emanates from the experience of financial market crises and the stresses of illiquidity associated with these episodes at both the national banking and international levels. In the context of strengthening the architecture of the international monetary system, there is now concerted action by national authorities and international organizations to reinforce financial systems and their resilience to shocks. With this in mind, the role of strong liquidity and currency risk management inter alia, has been acknowledged. ${ }^{3}$

${ }^{2}$ See Basel Committee (1993); BIS (1999); IMF (1998); Ohara (1995); and Dattels (1995).

${ }^{3}$ In response to the crisis in Asia, finance ministers and central bank governors from 22 systemically important countries prepared a report on strengthening national financial systems, emphasizing the modalities for liquidity and coining the term "systemic liquidity", which is adopted in this paper. (Report of the Working Group, 1998) 
Systemic liquidity refers to adequate arrangements and practices which permit efficient liquidity management, and which provide a buffer during financial distress. Systemic liquidity is viewed as the combination of bank liquidity management practices and the supporting liquidity infrastructure. This paper explores a framework for assessing the adequacy of arrangements for market liquidity with a view to evolving elements of a systemic liquidity policy. It argues that robust arrangements for liquidity are crucial to resilience and effective monetary operations and must provide confidence that liquidity can be mobilized and repaid on demand in a predictable and transparent manner. Such liquidity arrangements include several institutional elements which are described in the paper and involve a role for national authorities in promoting their adoption.

The following sections deal with the main constituent elements, as noted below. Section II reviews portfolio considerations affecting liquidity, particularly highlighting a measure of funding volatility. Section III outlines elements of a liquidity infrastructure. Section IV applies this framework to a sample of 14 countries, supported by more detailed case studies of Mexico and Argentina in Section V. Section VI draws policy conclusions.

\section{BANK PoRTfolio CONSIDERATIONS IN LIQUIDITY OPERATIONS}

\section{A. Issues in Volatility and Resilience}

Bank liquidity can be defined as the degree to which a financial institution is able to meet its obligations under normal business conditions. Liquidity is closely interlinked with confidence because its most generic function is to provide the bank and its customers with the reassurance that the bank's liability obligations can be met as they become due without necessarily having to roll these over or postpone access to credit. For this reason, an important objective of liquidity management operations is to engage in confidence enhancing practices (Bundesbank 1982; Federal Reserve, 1990; Group of 22, 1998). The core issue of bank vulnerability to sudden and sustained loss of liquidity (and loss of confidence) emanates from the volatility of funding relative to the liquidity of bank assets. In such circumstances of market uncertainty, market participants become less willing to trade or commit funds, and the decline in activity results in a loss of market liquidity. The following sections discuss funding volatility and asset liquidity, respectively.

\section{Determinants of funding volatility}

Funding volatility reflects how sensitive depositors or creditors are to events that undermine confidence. More specifically, it refers to the likelihood that bank depositors or creditors will, in a short period of time, withdraw their funds (or fail to roll them over at maturity) in response to a perceived weakness in an individual bank or banking system. The volatility of a particular liability is a function of institutional and economic factors. Typically, the key variables used to define the extent of volatility can be grouped into three broad areas: type of depositor, insurance coverage, and maturity. 


\section{Type of depositor or creditor}

The volatility or stability of a bank's liabilities also depends on the nature of the depositor or creditor. Institutional investors are relatively sophisticated, have access to banks' financial information, and have a fiduciary responsibility to safeguard their assets. As a result, they are prone to shifting investments and, hence, such investments are volatile. By contrast, household depositors tend to be more complacent, often due to their confidence in deposit insurance, but also due to their lower awareness of risk. Commercial depositors fall between the two groups in terms of volatility. While more aware of bank risk than household depositors, they are less able to act on these fears than institutional investors, since doing so typically requires unwinding and replacing complex banking relationships. $^{4}$

\section{Insured and collateralized liabilities}

Instruments covered by deposit insurance can be considered stable sources of funding, with the important caveat that insurance schemes that are not credible may not have this effect. Large-size deposits can be indicative of volatility, if the holder is either an institution or a relatively sophisticated individual. Foreign currency deposits may be volatile if they are large-size deposits or if they are excluded from deposit insurance or if there is uncertainty in about their coverage. ${ }^{5}$ However, as illustrated below, no a priori judgement about funding volatility can be made on the basis of currency denomination.

In the case of larger denomination instruments, uncollateralized liabilities are more volatile than those backed by collateral, assuming the pledge mechanism is credible to the creditor. An important precondition is that asset pledging is allowed and protected under the law. In the event of the borrower's bankruptcy or failure to comply with contractual terms in a collateralized transaction, the rights of the pledgee (lender) must be protected and be beyond doubt to provide confidence even under circumstances of stress (see Box 1). There must also be adequate market acceptance of assets as collateral, and trading and custody practices must carry no unusual risks to the lender. Collateralized transactions may be hampered by practices which constrain the execution of collateral or which affect

\footnotetext{
${ }^{4}$ The volatility of bank creditors will also be influenced by the unique experiences of creditors. For example, creditors who have experienced bank runs or state confiscation of deposits may be more sensitive to perceived risk than those whose experience is limited to a more stable environment.

${ }^{5}$ The exchange rate regime and its credibility play influence the liquidity properties of foreign exchange deposits. In some highly dollarized economies foreign currency deposits may be more stable than local currency deposits.
} 
the price of collateralized transactions, for example by requiring reserve holdings against repurchase transactions. ${ }^{6}$

\section{Box 1. The Liquidity of Pledgeable Assets}

Why do banks pledge assets? Banks pledge assets to obtain liquidity from illiquid assets (e.g., consumer and residential mortgage loans) or to diversify sources of liquidity. Asset pledging can diversify the funding because it attracts buyers who differ from outright buyers of an asset and from potential depositors. Asset pledging can also serve to obtain liquidity without triggering the recognition of a loss that might occur under a sale.

Perfecting the pledging process. For most bank assets, perfection requires that the creditor take possession. Pledged securities (whether physical or book-entry) might be held in custody by the creditor or by its custodial agent. For some bank assets (real estate, fixed assets, mortgage loans) the bank continues to hold the asset but a creditor's lien is noted legally. Perfection in this case involves a notification process. (e.g., via official registration, notification attached to an underlying document, or public announcement).

Valuation practices. Market practice should routinely ensure an appropriate relationship between the market value of collateral and the loan (e.g., a margin that reflects the terms of the repurchase agreement and price volatility of the underlying collateral). Valuation should include accrued interest.

Custody practices. If perfection involves possession of the collateral, this should be done by routine processes. There should be adequate safeguards against double-pledging of the same collateral.

Effective enforcement of creditor legal rights in the event of default. In case of collateralized borrowing, the lender should be able to liquidate the collateral immediately and not be subjected to a lengthy bankruptcy process.

Limited to liquidity management. Pledging should only be permitted in connection with liquidity management. The legal framework must ensure that pledging does not impinge on depositor rights.

\section{Instrument maturity}

On instrument maturity, it is generally held that the longer the time before a liability matures, the more stable (less potentially volatile) it is, on the presumption that the depositor is unlikely to leave until the deposit matures. In this regard, the remaining maturity is a superior measure to original maturity, although data for the former are often difficult to obtain. There is no standard maturity cut-off that divides volatility from stability, although some supervisory bodies use a one-year benchmark. Even so, in countries where banks are obligated by law to meet early withdrawal requests with only minor penalties, maturity may be less relevant to determining volatility.

\footnotetext{
${ }^{6}$ Many analysts view such assets as liquid if the volatility of their associated liabilities are properly captured (as liquid) in overall measures of liquidity. Balance sheet data do not necessarily distinguish between assets that are pledged and those that are not.
} 


\section{Liability management}

Liability management aims at controlling liquidity risk by limiting volatility gaps between asset and liabilities, and by assuring access to funding markets. In broad terms, techniques of limiting liquidity mismatches aim at extending the maturity of liabilities and increasing stable "core" deposits. A second group of techniques aims at assuring and improving funding market access. By diversifying funding sources by market segment, banks can reduce their vulnerability to market or counterparty disruptions and increase the probability that funding can be retained or replaced if there is a disruption. In managing funding relations, banks also establish contingency arrangements and often have bilateral/correspondent and last-resort arrangements from which funds can be raised on a temporary basis (Dacey and Bazel-Horowitz, 1990).

\section{Asset liquidity}

The liquidity of assets can be defined in close analogy to funding volatility. Negotiability, and maturity as well as the type of borrower, collateralization, and currency denomination are key components of asset liquidity, just as they are with funding volatility. An important difference is that assets are less likely to be covered by explicit insurance.

Asset liquidity can be obtained either by holding liquid paper, by managing the maturity distribution of nonliquid assets with a view toward the bank's liquidity needs, and/or by selling outright (or lending) collateralized claims on a repurchase basis. In this context, market arrangements for asset pledging are important. If an asset can reliably be pledged as collateral for a new liability, the asset can be treated as liquid.

Effective commercial liquidity management requires that sufficient liquid assets be held to meet normal business requirements (including reserve requirements) and that excess balances be minimized. Liquid assets, primarily cash and readily marketable securities, generally offer lower yields than other portfolio choices. Thus, under normal conditions, holding liquid assets is costly in terms of reduced profitability. ${ }^{7}$ The types of adjustment banks will consider in managing their assets will depend mainly on the magnitude of the deviation from desired balances, the asset's likely duration, the relative yields available on alternative types of investment and on the costs of different sources of funds. If the transaction costs of making an adjustment are large compared to the interest that could be earned on surplus balances or to the size of the penalty on a deficiency, the incentive to make the adjustment will be less.

${ }^{7}$ However, yields on liquid (government) securities may be higher than a reasonable return on investments; and under such circumstances, it may be highly profitable for banks to hold liquid assets. 


\section{B. Measuring Funding Volatility-An Aggregate Balance Sheet Approach}

Funding volatility of a bank can be judged by comparing liquid assets (including off-balance sheet items) to overall funding. ${ }^{8}$ In Figure 1 below, balance sheets for banks at two extremes are presented. On the left is a bank that relies on volatile funds to finance its investment in nonliquid assets. On the right is a bank with a significant margin of surplus stable funds (e.g., core deposits) to invest. Under liquidity stress, the bank that relies primarily on volatile funding is vulnerable to illiquidity and it may become insolvent if creditors permanently move their funds elsewhere. The bank with a low level of confidence-sensitive funds is less affected by liquidity stress because of the relative inertia of its depositors and because of the large portfolio of liquid assets.

Figure 1. Funding Volatility Concepts Focus on the Gap Between Liquid Assets and Volatile Liabilities Relative to Illiquid Assets

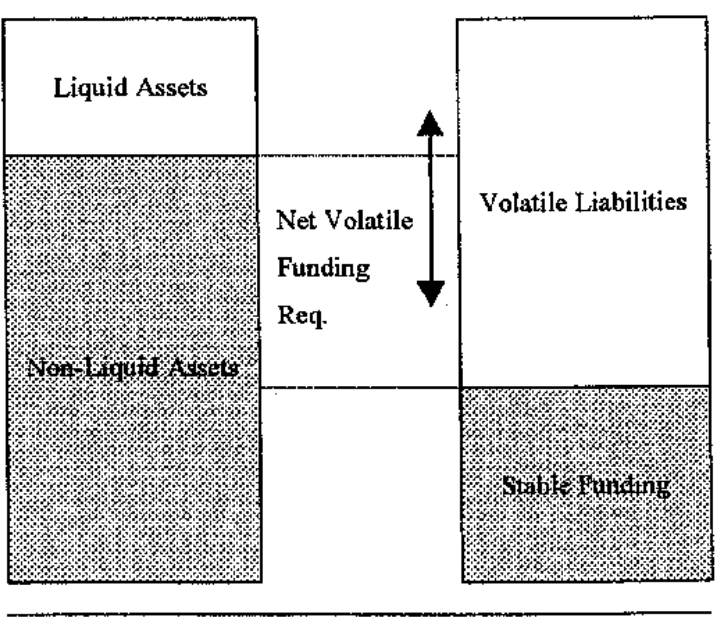

Illiquid Bank (vulnerable)

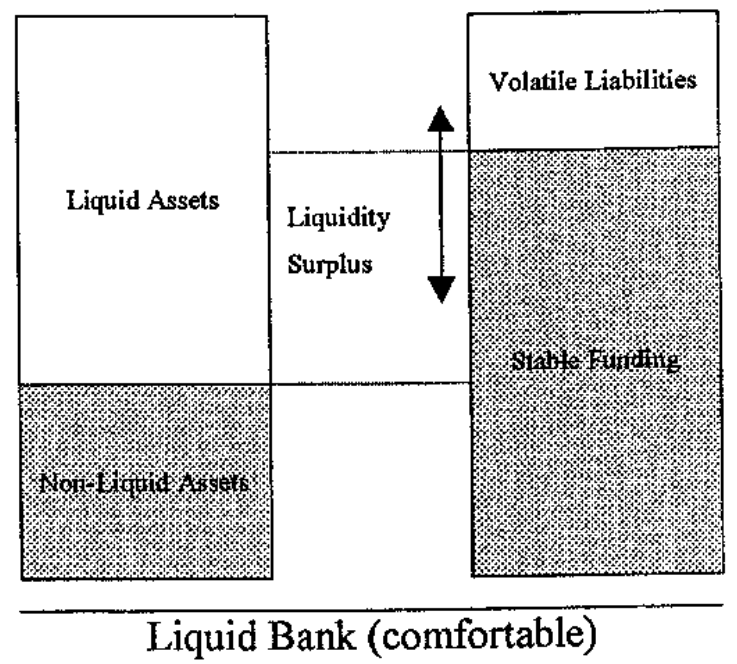

Liquid Bank (comfortable)

At the level of the individual bank, cash flow models are often used, which gauge cash inflows relative to cash outflows over different time horizons. Cash flow models allow for a dynamic analysis of liquidity which complements the static (balance sheet-based) approach taken here. However, in the absence of sufficiently detailed data, it

\footnotetext{
${ }^{8}$ Another standard indicator is a loan-to-deposit ratio which shows the extent to which a bank has committed its stable funds to clients in the form of loans. When loan commitments are low relative to the banks' stable source of funds, liquidity may be described as ample and vice versa. See, for example Basel Committee (1993). Other measures of funding volatility include direct empirical estimation of the volatility of liabilities, or analysis of interest spreads to derive a liquidity risk premia.
} 
is very difficult to use cash flow models for analysis of the entire banking system, moreover, balance sheet data are more readily available.

The balance sheet-based approach to assessing liquidity can be expressed in terms of the volatility ratio shown below. This volatility indicator measures the extent to which banks rely on confidence-sensitive, or volatile funds to finance its assets. Naturally, volatility analysis should fully incorporate any off-balance sheet items, (e.g. contingent credit lines) which often play an important role in liquidity management strategies. Funding volatility ratio: $\quad \frac{\text { VL-LA }}{\text { TA-LA }}=\frac{\text { (volatile liabilities) - (liquid assets) }}{\text { (total assets) }- \text { (liquid assets) }}$

Prudent liquidity management implies that a bank maintain at least sufficient liquid assets to cover volatile liabilities. In this case, the ratio is zero. More prudent banks would be expected to maintain liquid assets in excess of volatile liabilities. In this case, the ratio is negative. Less prudent banks, those that rely heavily on confidence-sensitive funds will have volatility ratios above zero (Table 1).

The ratio is scaled by illiquid assets in the denominator, which mirror volatility more accurately than if total assets were the scale factor. For example, if a bank's liquidity is measured as (VL-LA)/TA and the ratio is significantly positive, the bank can reduce the ratio merely by borrowing and investing more (raising VL and LA). In this case, the numerator stays unchanged but the denominator rises, lowering the overall ratio without lowering the bank's dependence on confidence-sensitive funds. On the other hand, if illiquid assets are used as the scale factor, a positive ratio cannot be reduced by such window dressing operations. Total assets and liquid assets would grow by the same amount, leaving the difference unchanged.

Table 1. Interpreting the Funding Volatility Ratio (VL-LA)/(TA-LA) 1/

\begin{tabular}{cll}
\hline Value & \multicolumn{1}{c}{ Occurs when } & \multicolumn{1}{c}{ Indicates } \\
\hline$>0$ & Volatile liabilities are not fully covered by liquid assets & High risk 2/ \\
0 & Volatile liabilities are fully covered by liquid assets & Intermediate risk \\
$<0$ & Volatile liabilities more than fully covered by liquid assets & Low risk \\
\end{tabular}

1/ VL=Volatile Liabilities; LA=Liquid Assets; and TA=Total Assets.

$2 /$ Can be corrected by raising stable funds (e.g., building domestic deposit base) and by reducing the share of illiquid assets (e.g., sale, maturing, or pledging).

While liquidity and volatility ratios are conceptually well understood, difficulties arise in applying these ratios in practice. The major problem is that it is not clear a priori 
which assets should be classified as liquid and which liabilities should be classified as volatile. This depends on the liquidity infrastructure. Available balance sheet data are generally more focused on providing information on the value of assets and liabilities rather than on liquidity. Moreover, rapid change in financial products makes it difficult to know what the liquidity properties are of a given instrument.

The liquidity properties of assets and liabilities depend on the institutional setting. In this regard, considerations of the existence of legal contract rights, the design of prudential and monetary instruments, foreign exchange regulations, as well as the overall variability of interest rates, and exchange rates are important. These can be summarized as the liquidity infrastructure.

\section{INFRASTRUCTURE FOR SHORT-TERM LIQUIDITY MANAGEMENT}

Effective liquidity management tools require explicit and developed contract law as well as other economic and institutional factors. Studies of liquidity management often take these factors for granted and, hence, the infrastructural prerequisites are a neglected dimension of liquidity management (de Villiers, 1996; Group of 22, 1998).

A good liquidity infrastructure should allow banks to operate in a reliable and transparent (confidence-enhancing") environment. Table 2 below lists key components which are grouped into two broad categories. A balanced infrastructure needs to provide support for the day-to-day liquidity management activities as well as a suitable support network for emergencies. For each category, a number of key factors are cited. These are not exhaustive but cover major aspects that are of particular relevance from a systemic liquidity perspective.

\section{A. Day-to-Day Liquidity Management Support}

The modalities of market structures to facilitate the recycling of liquidity have an important bearing on the capacity for liquidity management. Microstructures for interbank and secondary trading of securities must provide efficient price discovery and facilitate reasonable trading costs. The platform for these features is broad-based and even where necessary features exist (as discussed below), structural issues such as ownership patterns

\footnotetext{
${ }^{9}$ For example, in many countries, a mortgage loan would be considered an illiquid asset. However, if there is a well-developed secondary market for mortgage loans, a mortgage loan may be a liquid asset since it can easily be sold for cash.
} 
Table 2. Components of a Balanced Liquidity Infrastructure

\begin{tabular}{ll}
\hline Day-to-Day Liquidity Management Support & Safety Net-Support \\
\hline Information disclosure & Credible deposit insurance \\
Prudential liquidity rules & Lender of last resort \\
Creditor rights & \\
Monetary instruments, payments, microstructure & \\
Foreign exchange liquidity & \\
\hline
\end{tabular}

in the banking system, the types of creditors or debtors, and the degree of competition in markets, will impact on the infrastructure thereby affecting the depth of markets. ${ }^{10}$

\section{Market framework issues affecting liquidity}

\section{Information disclosure}

A basic underpinning for a good infrastructure relates to a requirement for efficient rules and practices for information disclosure. Public disclosure refers to the timely publication of meaningful financial data and for the purpose of informing market participants. ${ }^{11}$ Lack of disclosure and uncertainty about the true conditions of counterparts are invariably the main factors underlying market segmentation because the absence of regular and reliable information concerning the financial condition of financial institutions reduces the ability to assess counterparty risk. More generally, efficient dissemination of financial information also affects the interaction between informed and uninformed participants, thereby affecting price determination. Information can also affect the degree of market integration. Without this integration, orders arriving in the market will be sporadic and uneven and, thus, not fully representative of underlying supply and demand conditions. ${ }^{12}$

\footnotetext{
${ }^{10}$ Depth is as important as in thin markets deviations of market prices from their underlying equilibrium values may be caused by the size of the trader.

${ }^{11}$ Information in this regard can either be public (available to all market participants, such as publicly announced statistics) or private (not available to all market participants, but only to dealers).

${ }^{12}$ Integration has to be seen in the context of concentration of market liquidity. Notwithstanding the availability of many assets of different maturities and product design, market liquidity is usually concentrated in relatively few assets.
} 


\section{Prudential liquidity requirements}

In many countries, banks are subject to prudential rules on liquidity. These rules should be designed to compel banks to engage in prudent liquidity management, and are, thus, an important component of systemic liquidity infrastructure. Useful liquidity requirements provide market participants with a minimum acceptable standard of liquid assets relative to liabilities, defining assets and liabilities in terms of actual properties as reflect the prevailing institutional and legal framework.

Liquidity rules vary widely across countries, ranging from those that rely primarily on banks' own self-assessment of required liquidity to more rigid rules. Sometimes, liquid asset requirements are put in place primarily to create a captive market for hard-to-sell government bonds (Gulde, 1995). Such rules may well reduce the level of public confidence in bank soundness and, hence, tend to be detrimental to the liquidity infrastructure.

\section{Creditor rights}

An environment of confidence requires an effective legal and judicial structure supporting creditor rights. ${ }^{13}$ If creditor rights are well developed and creditors are confident that they will be given fair treatment in the event the bank experiences problems, all banks will find it easier to attract funds. In this regard, insolvency or default procedures must meet criteria of predictability. Relevant risk allocation rules should be clearly specified and applied consistently by the implementing institutions. While all creditors should receive equitable treatment, this does not necessarily mean equal treatment. Different creditors may have struck different arrangements with the debtor, for example, through the granting of collateral. For the benefit of all creditors, however, procedures must address issues of fraud and favoritism that arise in the context of financial distress. ${ }^{14}$ Creditor rights to information on proceedings dealing with the resolution of the affected institution and information on the debtor institution to ensure that decisions are informed are both critical elements of a confidence-enhancing framework.

${ }^{13}$ Claessens et.al (1999) and La Porta et.al. (1997). Most of the literature on creditor rights refers to nonbank enterprises. Nevertheless, the criteria used to assess creditor rights are relevant for banking. These are the timetables (number of days) for reaching judgement, the rights of management during resolution, high priority for secured creditors, and automatic stay for assets. Similarly, criteria for court efficiency (costs, duration, etc.) have been established.

${ }^{14}$ Given the importance of international finance, it is essential that there is no discrimination against foreign creditors. 


\section{Monetary instrument design affecting liquidity}

Prevailing monetary arrangements, design aspects of central bank instruments, and arrangements for payments and money market operations bear directly on banks' ability to manage short-term liquidity. ${ }^{15}$ High transactions costs, for example, arising from rigid instrument design and trading rules, and infrequent clearing arrangements can discourage trades and contribute to price volatility (Dattels, 1995). The relevant design features of instruments affecting liquidity management include reserve averaging, rules of access as well as volume, maturity, and rates of interest on standing facilities. Another significant design feature is the extent to which instruments place restrictions on the asset/liability management of banks.

\section{Reserve requirements}

The role of reserve requirements in liquidity management depends on the rules of reserve accounting (averaging provisions, contemporaneous or lagged reserve accounting, and carry-over provisions). More generally, reserve requirements are most compatible with liquidity management where banks hold reserve assets with liquidity characteristics which correspond to their needs. As noted earlier, effective cash management requires that sufficient liquid assets are held to meet normal business requirements. Where this voluntary demand for liquid assets coincides with the requirement for reserve holdings, the requirement does not constitute a problem for banks if they are generally able to mobilize these required reserves for liquidity management purposes. If reserve requirements are set very low, banks have less leeway through averaging to manipulate their reserve positions without the risk of incurring the penalty of noncompliance. In such cases, banks would have to voluntarily maintain higher levels of reserves. ${ }^{16}$

Contemporaneous measures of reserve requirements closely link the requirement with movements in bank deposits and so provide liquidity managers with immediate information on funding needs. The disadvantage, however, is that banks do not know their exact reserve requirement until the testing date. This could be problematic for banks that have difficulties in consolidating their daily positions or where intrabank accounting systems and methods of transferring funds between branches are weak. For these reasons, a lagged measure of reserve requirements may actually help banks to determine their reserve requirements more precisely, hence improving liquidity management.

Differentiated reserve requirements complicate liquidity management to the extent that they could induce banks into assuming maturity and interest rate structures for their

${ }^{15}$ See, for example, Bank of England (1981); Bundesbank (1982)

${ }^{16}$ The maturity profile of a bank's liability often understates actual liquidity as deposits are normally not demanded at the end of term. See Fed New York (1990). 
portfolio which could be suboptimal or at least require them to manage potential mismatches. (Prestopino, 1994).

\section{Standing facilities}

Standing facilities, which are accessed at the initiative of commercial banks, provide liquidity, usually against collateral, to meet transitional liquidity needs of banks. In settlement facilities and in some rediscount arrangements, credit is provided at market or below market rates. In the latter case, many central banks establish volume limits on access to this window or alternately limit usage through moral suasion. For commercial bank liquidity, management, rules of access, the volume of credit allowed, maturity and rates of interest on the credit available are all relevant design features. In this regard, many countries operate standing credit facilities most often with unlimited volumes of credit at market or above-market rates. In the case of rediscount operations, the bulk of credit is restrained by penalty rates of interest rather than volume restrictions. Some countries restrict the number of banks which can access overnight standing facilities, the frequency of access, the intervals between access, or have cumbersome application procedures which sometimes result in delays in the receipt of value. Naturally, such restrictions reduce the usefulness of standing facilities for liquidity management.

\section{Asset/iability restrictions}

Restrictions on the asset side of portfolios include practices affecting the volume of asset trading allowed, including restrictions which create captive markets for government securities and restrictions affecting the development of markets in securities and other assets. Where securities qualify as a reserve asset to meet reserve requirements, banks hold a certain proportion of liabilities in the form of securities. The same applies when using a strict liquid assets ratio with government securities as the main eligible asset. These restrictions (if binding) limit the volume of securities which can be readily used to realize liquidity in the short run. Some countries impose restrictions on the loan portfolio of banks by stipulating proportions to be lent to particular sectors or set absolute quantitative ceilings on outstanding credit. In the former case, the restriction limits the ability of banks to sell loans affected by the stipulation, while in the latter case income is constrained and so reduces the incentive to sell these assets in the event that liquidity is needed. Ceilings on loan rates or interest spreads reduce the flexibility to price loan assets for sale.

Similarly, several countries have restrictions on liability management. Interest rate ceilings on deposits restrict the ability of banks to mobilize funds in general. Differential reserve requirements could also increase the costs of mobilizing particular deposit maturities, as would marginal requirements, which could affect the costs of all incremental deposits mobilized. Some countries also place restrictions on the geographical domain of business for banks. While such restrictions can arise purely from a market response to a bank not well known outside of its main locale, restrictions on branching and those on domain add to these difficulties. Several countries also place restrictions on interbank activity either through taxing interbank trading (by applying reserve requirements) or by directing portions of 
interbank trade. This tax not only increases the price of interbank transactions but also can affect their maturity. ${ }^{17}$ In other cases, central banks have encouraged sound banks to dedicate a portion of reserve holdings to interbank placements to assist banks facing liquidity problems.

\section{Payment system arrangements}

An integral part of the decision framework for bank management of short-run liquidity relates to the technical and institutional characteristics of payment and settlement arrangements, including the central banks' attitude to end-of-day marginal financing. In this regard, the design of standing facilities and modalities of reserve requirements have important bearing on liquidity funding decisions.

In the arrangements for payments and settlement, at least three factors help reduce the need for precautionary balances (Borio, 1997). First, settlement procedures should be designed to allow banks to borrow and lend among themselves toward the end of the day after settlement positions are known or can be estimated with a comparatively small margin of error. ${ }^{18}$ If this is allowed then, provided the interbank market among participants works smoothly, the institutions can be reasonably confident of obtaining funds at the going market rate. A second factor relates to the expectation of being able to finance imbalances at a rate with no penalty. Many central banks seek to ensure that sufficient funds are available in the system so that participants do not need to turn to them for end-of-day assistance, which is then only provided at penalty rates. Finally, this arrangement, if supported by moral suasion discouraging banks from turning to the central bank, in turn will encourage the development of interbank markets. ${ }^{19}$

\section{Foreign exchange liquidity}

International banks operate in more than one currency, and must, therefore, include foreign exchange considerations in their liquidity management. Access to liquidity in foreign exchange is affected by a number of different factors from those affecting

\footnotetext{
${ }^{17}$ If the liability to which reserve requirements apply is measured periodically (as opposed to being averaged), banks would have an incentive to avoid the tax on the day of measurement. This could lead to transaction maturities of a length only within the measurement period. On the day of measurement, volumes traded could fall and the price of interbank trades could rise, leading to spikes in interbank rates around the period of measurement.

${ }^{18}$ The same effect could be achieved but with increased payments risk by extending the settlement period to next-day settlement, for example.

19 The Lamfalussy report (1990) and its recent update BIS (1999) spell out in more depth the framework for best practice payment systems.
} 
liquidity in domestic currency. In this regard, banks operating in highly dollarized economies are faced with special challenges. For example, deposits in domestic currency may prove less stable than those denominated in dollars.

Specific market and institutional factors affecting foreign exchange liquidity include linkages between local and external financial markets, which will have an important impact on liquidity in the local foreign exchange market. A network of correspondent relationships or cross-border banking networks involving domestic and foreign banks and, in particular, foreign bank branches and subsidiaries can improve domestic access to foreign exchange liquidity. However, at the same time, correspondent relationships are costly.

Box 2. Should Local and Foreign Currency Liquidity Be Analyzed Separately?

When the involved currencies are fully convertible and can easily and reliably be converted, liquidity measures can be viewed in the aggregate. In essence, this requires a well established, credible exchange regime. A sudden need to pay off liabilities of one currency can be met by issuing new liabilities or liquidating assets of another currency.

For thin currency markets or markets with limited foreign currency availability, interbank foreign exchange lines are limited and vulnerable to disruption. When forward hedging is unavailable, the fungibility (convertibility) assumption may be unwarranted for liquidity management purposes. Sufficient currency may not always be available. Alternatively, spot transactions can be performed, but the banks may find themselves unable to hedge against the resulting net foreign exchange positions. The unhedged use of "cross-currency liquidity" might well be viewed as an unacceptable risk, whether or not there are formal limits on foreign exchange open positions. If fungibility is not assured, currency-specific measures of liquidity should be used in addition to the aggregate figures.

There may be other reasons for keeping separate accounts. The volatility of liabilities and liquidity of assets may vary by currency. Foreign-currency creditors are often more volatile than their domestic counterparts. This may be either because foreign currency holders may have more choices or are more vulnerable themselves to competitive pressures.

Access to liquidity in foreign exchange and the transferability of liquidity between domestic and foreign currencies will be reduced by capital controls (e.g., gross limits on the size of banks' external correspondent balances and required approvals for borrowing abroad), either in the home country or in the currency issuing country. The design of prudential controls on open foreign exchange positions can also have an impact on access to foreign exchange liquidity. For example, very tight limits on the foreign exchange net position can constrain banks' ability to manage liquidity through currency conversion. Separate limits on net spot and forward transactions or other types of restrictions on the use of derivatives will also limit the incentive for developing hedging mechanisms that can improve management of liquidity and other types of risk. ${ }^{20}$

\footnotetext{
${ }^{20}$ The design of monetary instruments can also affect foreign exchange liquidity. For example, a requirement to hold required reserves on foreign currency deposits in foreign, continued
} 


\section{B. Safety-Net Infrastructure}

Deposit insurance and emergency credit provisions are part of the safety net which plays a role when banks are experiencing liquidity or solvency difficulties. A system of depositor protection that guards the holders of small deposits when their bank fails has in recent years become part of safety net arrangements in a number of countries. A well-designed deposit insurance system can strengthen incentives for efficiency and good governance for banks. With strong incentives for bank owners, managers, depositors, borrowers, and regulators to keep the system sound, a well-designed insurance scheme can encourage capitalization and discourage excessive risk taking by charging risk-adjusted premiums. Such systems should also encourage sophisticated depositors to exert market discipline by demanding disclosure of reliable information on the condition of banks (Garcia, 1999). This can be achieved by appropriate caps on insurance coverage.

Some central bank regulations include emergency credit arrangements to lend to banks perceived to be solvent but illiquid. These are distinct from normal standing facilities that provide overnight support to facilitate interbank settlement or to maintain interbank interest rates within a corridor. In fact, emergency credit arrangements are sometimes separate from the central bank and may take the form of liquidity consortia, called upon short notice. Most commonly, in order to minimize moral hazard, however, there is no ex-ante specification of such facilities. ${ }^{21}$ Where such emergency facilities exist, the focus is on early assessment of the solvency of the affected institution. Such lending can only be a stop gap measure since the credit risk assumed by the central bank can be significant.

In periods of banking stress, the factors precipitating emergency central bank liquidity support and recycling arise from a desire to avert systemic settlement failure, or as emergency support to banks experiencing deposit runs. Both conditions often arise from real or prospective flight of depositors to quality assets and institutions, and the inability of the troubled bank to either liquidate sufficient assets or raise new liabilities in the money market at a pace sufficient to match the outflow of funds, with resulting threats to the payment system.

rather than domestic, currency will provide a greater liquidity cushion against large deposit withdrawals in foreign exchange. Such a requirement will also eliminate the demand for additional liquidity to meet reserve requirements in the event of a depreciation of the domestic currency.

${ }^{21}$ In this regard a notable exception is the Federal Reserve Board's description of facilities under its discount window. 
In providing support, the central bank implicitly assumes the market risks that either depositors or money market lenders have been unwilling to bear. Support is given on the presumption that this minimizes costs that would arise in case of wide-scale disruption to the intermediation process. To minimize credit risk, these facilities are invariably collateralized - even where the collateral is not as liquid as that which the market would have required for short-term transactions. The overarching caveat to such operations is the need to rapidly determine prospective solvency. ${ }^{22}$

\section{The Importance of a Balanced Liquidity Infrastructure}

A balanced liquidity infrastructure should primarily rely on factors for day-to-day liquidity management (as outlined in Table 2) and rely on safety-net features for emergencies only. A balanced infrastructure allows systemic resilience to shocks. In many countries rigidities exist in the factors necessary for smooth day-to-day operations. In some cases, the authorities hope to counterbalance the shortcomings in the financial infrastructure by providing overly generous guarantees and support mechanisms. Infrastructures relying heavily on crisis control are weak relative to those with more balanced qualities. The measure of funding volatility and the factors that affect a balanced infrastructure are very closely linked. Dysfunction in the infrastructure could induce a need for larger holdings of liquidity. In this situation, the funding volatility ratio may appear sufficiently negative, masking underlying low resilience to shocks.

The importance of a balance is highlighted in the two in-depth case studies included in Section V. While in both Argentina and Mexico volatility ratios were high, Mexico's banks operated in a very weak and unbalanced infrastructure which relied heavily on the safety net. Argentina's infrastructure also had significant shortcomings and lacked a safety net completely. However the emphasis on day-to-day factors helped Argentina avert a more serious financial crisis in 1994. In the aftermath of the crisis, both countries have established stronger, and more balanced infrastructure.

\section{SYSTEMIC LIQUIDITY FRAmEWORK: STYLIZED APPLICATION}

In applying and interpreting the framework developed, a group of 14 countries was chosen, all with relatively developed financial markets and with reasonably large internal

\footnotetext{
${ }^{22}$ Even where the modalities of safety nets are not explicitly defined ex-ante, they can support confidence in the market. This can be beneficial in facilitating excess reserve recycling outside the central bank. Nonetheless, significant moral hazards can be inherent, if these arrangements are badly designed. Good banks (or depositors) could lose the incentive to monitor troubled banks and price their credit risk appropriately.
} 
markets. ${ }^{23}$ The countries were chosen to represent countries with and without recent systemic liquidity crises. ${ }^{24}$ Data availability and IMF experience with the countries' financial market structure were important considerations in choosing the sample.

\section{A. Volatility Ratio of $\mathbf{1 4}$ Countries}

In approximating a volatility ratio, a private database containing bank by bank data (Thomson Bankwatch) was used. This database allows the following definition for the three elements of the volatility ratio, total assets, volatile liabilities, and liquid assets. Total assets are defined as reported assets plus off-balance sheet items, consumer liabilities on acceptance and bills rediscounted. Liquid Assets are those on- and off-balance sheet items immediately available as cash, or quickly convertible into cash, e.g., cash, trading securities, government securities, claims due from banks, and short-term marketable securities. Volatile liabilities are approximated using "total borrowed funds," which includes average liabilities of interbank borrowings, notes, bills, bonds, and other debt instruments issued plus other borrowings, regardless of maturity.

The volatility ratio was calculated for each country for a seven-year time period from 1992-98. Table 3 shows the results and Figure 2 displays the average values for volatility indicators for each country, where the countries are in ascending order of their volatility ratios. The data show that the ratio is negative in India, Malaysia, and the industrial countries except for Japan, reflecting relatively conservative (prudent) liquidity management for the banking sectors taken as a whole. By contrast, for Argentina, Brazil, Japan, Mexico, Thailand and Indonesia, the ratios were positive, indicating higher risk profiles.

In addition, a dispersion indicator was calculated to measure differences among banks within the banking sector. Dispersion was measured as an unweighted average of volatility ratios in one year (1997). For most countries, the dispersion indicator confirms the findings of the aggregate picture. However, for Argentina, the dispersion volatility ratio is negative because the majority of banks has negative ratios, while the large banks have positive ratios. This could be a sign that larger banks are more exposed to confidence-sensitive funding than smaller banks. In Malaysia and Thailand the aggregate

\footnotetext{
${ }^{23}$ The countries are: Argentina, Brazil, Canada, Germany, France, India, Indonesia, Japan, Korea, Malaysia, Mexico, Thailand, United Kingdom, and United States.

${ }^{24}$ Systemic liquidity crises were experienced in: Indonesia, Japan, Korea, Mexico, and Thailand.
} 
Table 3. Volatility Ratios for Selected Countries

Commercial Banks, 1994-98 1/

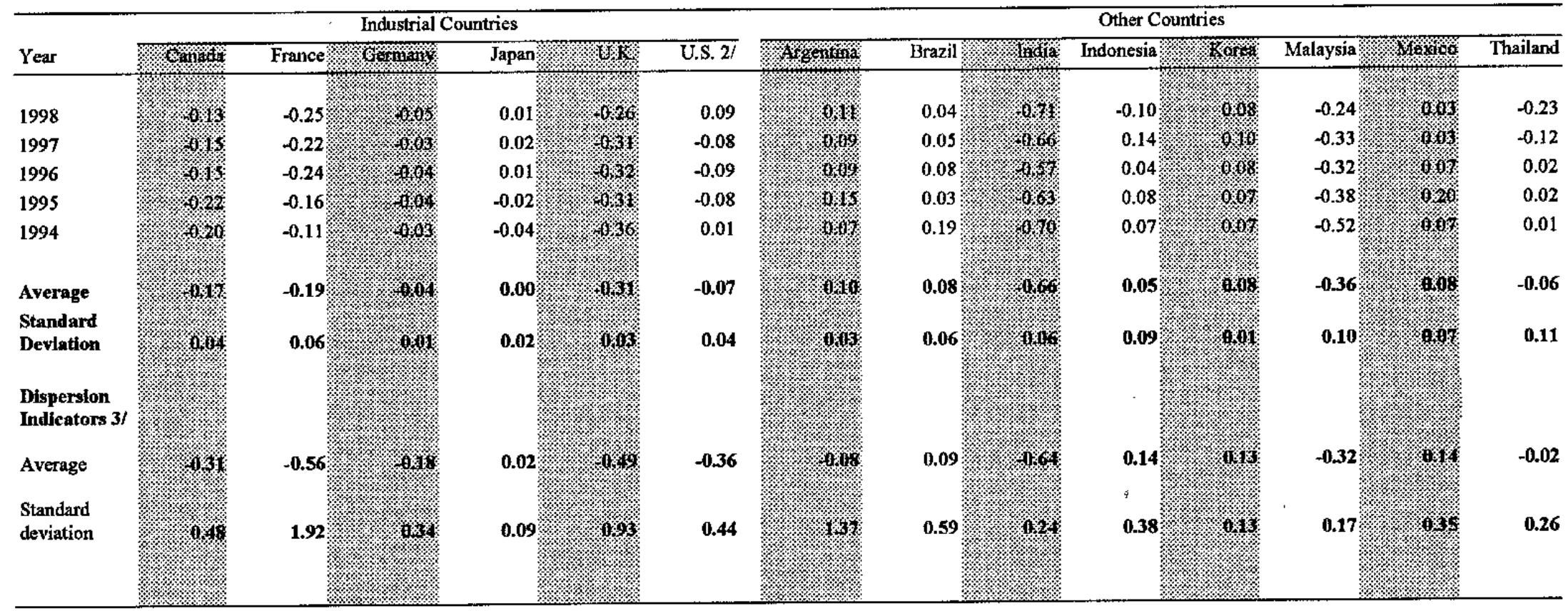

Sources: Bankstat and Thomson BankWatch, Inc.

$1 /$ Data for 1998 are incomplete.

Volatility ratio is calculated as $\mathrm{V}=(\mathrm{BF}-\mathrm{LA}) /(\mathrm{TA}-\mathrm{LA})$, where $\mathrm{BF}=\mathrm{Total}$ Borrowed Fund; LA=Liquid Assets; and TA=Total Assets.

2/ U.S. estimates are based on holding companies.

3/ Unweighted average of volatility ratios, 1997. Dispersion is a measure of differences among banks. 
Figure 2. Average Highest, and Lowest Values of Volatility Ratios for Selected Countries During 1992-98, in Percent

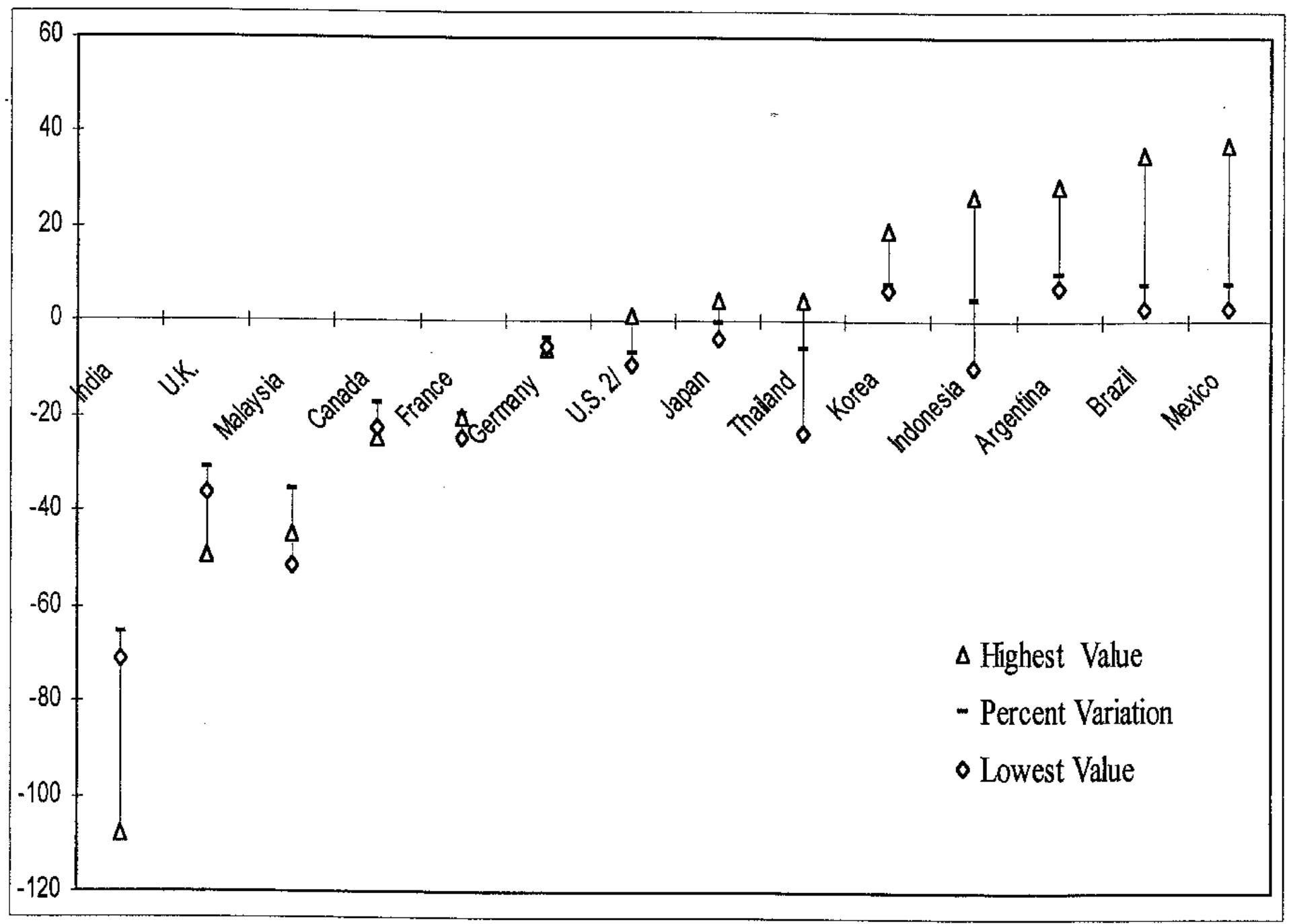


(multi-year) figures yield almost the same results as the bank by bank dispersion ratio. This may suggest greater homogeneity in bank behavior than in other countries.

Several shortcomings of the data must be taken into account. Aggregate data on all commercial banks often hide very substantial discrepancies within the banking sector between strong and weak banks. In some countries, the banking sector is segmented and vulnerabilities arise from weaknesses of some institutions. Furthermore, the database does not differentiate between domestic and foreign currency. For reasons discussed above in many cases, this may introduce a bias in favor of stability. Section V below illustrates how additional information can be used to fine-tune volatility ratios. In both case studies the more in-depth study of volatility ratio components leads to upward revisions (more volatility).

\section{B. Systemic Liquidity Infrastructure}

As discussed above, volatility ratios should be interpreted in the context of the infrastructure for liquidity management. Table 4 is an attempt to map the liquidity infrastructure of the selected countries at end-1997. The observations shown in this table are rough approximations of the factors discussed above. This reflects the difficulty in producing comparable data. For example, to make judgements on disclosure quality countries' adherence to International Accounting Standards (IAS) could be a benchmark. However, adherence to IAS is not monitored in a consistent way and a database maintained by the International Accounting Standards Committee contained only a few self-assessments. Therefore, no measure for disclosure could be included .

Prudential liquidity was measured by whether or not banks are required to maintain liquid reserves relative to some measure of illiquid assets. No attempt was made to assess the adequacy of prudential liquidity rules except to ensure that the rules are written from a prudential point of view rather than liquid asset requirements which force banks to purchase government bonds.

The third column shows observations on creditor rights and the efficiency of court systems. This issue has received considerable attention in the wake of the recent financial crises and as noted above, empirical studies of creditor rights and court system efficiency in various countries . For Asian countries, there are two recent surveys of bankruptcy codes available, one from the World Bank (La Porta, 1997 and Claessens et.al., 1999). For some other countries, the World Bank and IFC have produced studies of bankruptcy procedures and creditor rights. Naturally, these studies constitute first attempts to "rate" countries in these respects and the results must, therefore, be considered with great caution. Table 4 reproduces judgments from the above sources. In the absence of such studies, no entries were made. This does not indicate a deficiency of creditor rights.

The confidence-enhancing aspects of instruments, payments, and microstructure were approximated using two separate indicators, one to mirror market depth and one to 
indicate any restrictions on liquidity transformation imposed by the authorities. Market depth was approximated using data on turnover in markets for government securities.

Ideally, foreign currency borrowings would be represented as a ratio of foreign currency liabilities relative to total bank assets. However, this information is just beginning to be published in the MMF's International Financial Statistics (IFS) and is not available for the full sample of countries. As a proxy, therefore, Table 4 shows foreign liabilities (liabilities to foreign residents) of money center banks relative to total liabilities (but excluding interbank deposits). As shown in Table 4, for most countries in the sample, foreign liabilities play a significant role, thus adding complexity to liquidity management for banks. Foreign liabilities are modest (at or below 10 percent) in India, Japan, Korea, Malaysia, Mexico, and the United States.

In the case of deposit insurance, the guiding criterion was whether an explicit scheme is in place (Garcia, 1999). No attempt was made to determine whether these schemes are credible, and, hence, effective in making covered deposits a stable base of funding. Lenderof-last-resort arrangements were not mapped because often these are not specified ex ante as discussed above.

\section{Summarizing Information on Systemic Liquidity Frameworks}

With more reliable information on volatility ratios and the liquidity infrastructure, a quantification of systemic liquidity could be established with a view of rank ordering the countries in the sample group. The observations in Tables 3 and 4 could be aggregated into a composite indicator which could be used to rank order the countries by strength of systemic liquidity environment. Table 5 below lays out conceptually, how countries could be grouped into four broad categories without attempting to place individual countries. The table measures the volatility ratio along the vertical axis and the infrastructure on the horizontal axis. The lower right-hand quadrant, marked as "double plus" would be the best-case scenario, where good bank liquidity management (represented by negative volatility ratios) is supported by a strong and balanced infrastructure. As discussed above, this finding would have to be supported by a relatively homogeneous and unfragmented financial sector. 
Table 4. Liquidity Infrastructure of 14 Selected Countries, 1997

\begin{tabular}{|c|c|c|c|c|c|c|}
\hline \multirow{2}{*}{$\begin{array}{l}\text { Criteria } \\
\text { Countries }\end{array}$} & \multirow[b]{2}{*}{$\begin{array}{l}\text { Prudential } \\
\text { Liquidity } \\
\text { Rules } 1 /\end{array}$} & \multirow[b]{2}{*}{$\begin{array}{l}\text { Creditor Rights and court } \\
\text { efficiency } 2 /\end{array}$} & \multicolumn{2}{|c|}{$\begin{array}{c}\text { Central Bank Instruments, Payments, } \\
\text { Microstructures 3/ }\end{array}$} & \multirow[b]{2}{*}{$\begin{array}{c}\text { Foreign } \\
\text { Borrowings 4/ }\end{array}$} & \multirow[b]{2}{*}{$\begin{array}{c}\text { Explicit } \\
\text { Deposit } \\
\text { Insurance 5/ }\end{array}$} \\
\hline & & & $\begin{array}{c}\text { Govt } \\
\text { securities } \\
\text { market } \\
\text { turnover }\end{array}$ & Portfolio restrictions & & \\
\hline Canada & Yes & Well developed & 21.9 & None & 19.3 & Yes \\
\hline France & Yes & Well developed & 33.8 & Liquid asset ratios & 32.1 & Yes \\
\hline Germany & Yes & Well developed & $\cdots$ & None & 17.7 & Yes \\
\hline Japan & No & Well developed. & 6.9 & $\underset{r}{\text { None }}$ & 10.2 & Yes \\
\hline UK & No & Well developed & 7.0 & None & 51.4 & Yes \\
\hline United States & No & Well developed & 22.0 & None & 9.4 & Yes \\
\hline Argentina & Yes & Strengthened in 1995 & $\cdots$ & None & 18.8 & Yes \\
\hline Brazil & No & $\begin{array}{l}\text { Concordata delays action, } \\
\text { reduces value of claims. }\end{array}$ & 10.3 & $\begin{array}{l}\text { Differential reserve } \\
\text { requirements }\end{array}$ & 13.2 & Yes \\
\hline India & Yes & n.a. & 3.6 & $\begin{array}{l}\text { Deposit rate ceilings, } \\
\text { liquid asset ratios/, } \\
\text { secondary reserve } \\
\text { requirements }\end{array}$ & 4.1 & Yes \\
\hline Indonesia & No & $\begin{array}{l}\text { Insolvency law and } \\
\text { courts weak, rarely used } \\
\text { in practice }\end{array}$ & n.a. & $\begin{array}{l}\text { Ill-designed standing } \\
\text { facilities }\end{array}$ & 14.2 & No \\
\hline Korea & Yes & $\begin{array}{l}\text { Well developed but } \\
\text { inexperienced with } \\
\text { restructuring }\end{array}$ & 8.3 & Deposit rate ceiling & 8.7 & Yes \\
\hline Malaysia & Yes & $\begin{array}{l}\text { Legal system developed } \\
\text { but procedures not well } \\
\text { established. }\end{array}$ & 4.0 & $\begin{array}{l}\text { Interest spread } \\
\text { restriction, limited } \\
\text { Reserve averaging, } \\
\text { Liquid asset req., } \\
\text { limited collateral }\end{array}$ & 8.5 & No \\
\hline Mexico & Yes- & $\begin{array}{l}\text { "Suspension" practice } \\
\text { strongly favors debtors, } \\
\text { reform in preparation } \\
(1999)\end{array}$ & n.a. & None & 3.3 & Yes \\
\hline Thailand & No & $\begin{array}{l}\text { Very slow process. No } \\
\text { commercial courts exist }\end{array}$ & n.a. & None & 15.9 & Yes \\
\hline \multicolumn{7}{|c|}{$\begin{array}{l}\text { 1/ Canada: Part X485 Banking Law; France: Regulation 88-01; Germany: Banking Act Section 10; India: Banking Act Art. 24; Korea: just } \\
\text { introduced in 1999; Malaysia, Article } 38 \text { Banking Act; Mexico Bank of Mexico regulation; } \\
\text { 2/ Criteria as discussed in Section III A. Sources: Canada, France, Germany, UK, and US (White, 1994); Brazil (Mendes, 1995), Indonesia, } \\
\text { Japan, Korea, Malaysia, Thailand (Claessens, 1999 and World Bank/IFC Documents); Mexico (Lubrano 1996) Argentina (IFC) } \\
\text { 3/ Sources: BIS (1999) and; Central bank reports. In cases the data could include repo transactions. India: T-bills only. } \\
\text { 4/ Source: IFC Statistics. } 1988 \text { Foreign liabilities of money center banks in percent of total liabilities (excluding interbank claims). India: } \\
\text { Foreign currency liabilities (IMF staff estimates). } \\
\text { 5/ Garcia (1999). }\end{array}$} \\
\hline
\end{tabular}


Table 5. Classifying Systemic Liquidity Environments

\begin{tabular}{|l|l|}
\hline $\begin{array}{l}\text { - Systemic Vulnerability } \\
\text { Exposure to Volatile Funding: High }\end{array}$ & $\begin{array}{l}\text { + or - Weakness of Management } \\
\text { Exposure to Volatile Funding: High } \\
\text { Infrastructure: Weak }\end{array}$ \\
\hline $\begin{array}{l}\text { - or + Weakness of Infrastructure: Baianced } \\
\text { Exposure to Volatile Funding: Low } \\
\text { Infrastructure: Weak }\end{array}$ & $\begin{array}{l}\text { ++Systemic Robustness } \\
\text { Exposure to Volatile Funding: Low } \\
\text { Infrastructure: Balanced }\end{array}$ \\
\hline
\end{tabular}

The upper left-hand quadrant is the weakest scenario, where high level exposure to funding volatility coexists with a weak liquidity infrastructure, indicating systemic vulnerability. The lower right-hand quadrant represents the most robust structure where banks are prudent managers of their exposure to confidence-sensitive funds and operate in a supportive infrastructure. On the upper right-hand quadrant, banks are operating in a supportive infrastructure but liquidity management of banks displays excessive exposure to volatile funding, thus jeopardizing systemic stability. Conversely, the lower left quadrant is the case where banks are conservatively managed but operating in a weak infrastructure. This may indicate particular vulnerability to contagion. With more reliable and uniformly applicable information, it may be possible to establish empirically whether infrastructure is more important than volatility ratios of banks.

\section{SySTEMIC LIQUIDITY FraMEWORK: CASE STUDY APPLICATION- THE LIQUIDITY CRISES OF MEXICO AND ARGENTINA}

\section{A. Mexico 1994-95}

In 1991-92, Mexico reprivatized eighteen commercial banks that had been nationalized ten years earlier. The prices paid were high, often at multiples of three to four times book value. Bank managers found themselves under immediate pressure to generate high earnings to justify such high prices, and assets continued to grow rapidly at what appeared to be healthy spreads. However, rapid growth was accompanied by asset quality deterioration, which was not disclosed due to weak accounting practices. While bankers concentrated on the asset side of their balance sheets, few invested in the infrastructure and product development necessary to build a deposit franchise, focusing instead on raising funds in the domestic and foreign wholesale money markets. The result was that as banks funded their deteriorating assets with volatile deposits and vulnerability to a loss of confidence grew.

In December 1994, after a year of political uncertainty and a drain on the Banco de Mexico's dollar reserves, the government devalued the peso by 15 percent. This encouraged more speculative attacks, and a few days later, Mexico allowed the peso to float freely. It fell to 56 percent of its early-December value. Peso interest rates rose sharply from 13.7 percent 
(28-day treasury bills) on December 15 to 31.0 percent at year-end and then to over 80 percent a few months later. Both dollar and peso deposits declined although, as discussed below, the impact on bank liquidity was somewhat divided between dollar and peso liabilities. Extensive emergency financial support eventually stabilized the banks sufficiently to allow the broader task of restructuring the banking system (Carstens and Schwarzt, 1998).

\section{Bank liabilities}

A simplified picture of Mexican bank liabilities just prior to the crisis is shown in Table 6. Liabilities are classified as stable and volatile, based on standard characteristics discussed in Section I and some additional institutional factors that played a role in Mexico.

Sight deposits, which can easily be moved but may benefit from some inertia were evenly divided into stable and volatile. With better knowledge of depositor behavior and types of depositors (institutional, commercial, government, etc.), more accurate classification would be possible. Non peso accounts were assumed to be volatile, although this may exaggerate the volatility. Of the banks' direct funding, about seventy percent were large, negotiable peso-denominated promissory notes. Foreign currency funding are euro CDs, which were favored because of their liquidity.

Repurchase agreements were classified as volatile due to their short term nature. Accordingly, the underlying assets, mainly government securities were classified as liquid (Table 7).

Table 6. Mexico: Commercial Banks Liabilities (Percent of Total Assets) September 30, 1994

\begin{tabular}{|c|c|c|c|c|c|c|}
\hline & \multicolumn{3}{|c|}{ All Currencies } & \multicolumn{3}{|c|}{ FC-Denominated Only } \\
\hline & Total & Stable & Volatile & Total & Stable & Volatile \\
\hline Sight Deposits & 14 & 7 & 7 & 1 & $\ldots$ & 1 \\
\hline Direct Funding & 31 & 9 & 22 & 4 & $\ldots$ & 4 \\
\hline Repurchase Agreements & 21 & $\ldots$ & 21 & - & $\ldots$ & - \\
\hline Interbank Liabilities & 9 & $\ldots$ & 9 & 7 & $\ldots$ & 7 \\
\hline Bonds, Acceptances, Other & 17 & 13 & 4 & 3 & $\ldots$ & 3 \\
\hline Subtotal & 92 & 29 & 63 & 15 & $\ldots$ & 15 \\
\hline Capital, Subordinated debt & 8 & $\cdots$ & $\ldots$ & $\cdots$ & $\cdots$ & $\cdots$ \\
\hline Total & 100 & & & & & \\
\hline
\end{tabular}

Source: Comisión Nacional Bancaria y de Valores, Boletín Estadístico de Banca Múltiple, March 1995. 
Table 7. Mexico: Commercial Banks Assets (Percent of Total Assets) September 30, 1994

\begin{tabular}{|c|c|c|c|c|c|c|}
\hline & \multicolumn{3}{|c|}{ All Currencies } & \multicolumn{3}{|c|}{ FC-Denominated Onlv } \\
\hline & Total & Illianid & Lianid & Total & Illianid & Liamid \\
\hline Government securities & 0.4 & $\ldots$ & 0.4 & $\ldots$ & $\ldots$ & $\ldots$ \\
\hline Fixed income securities & 5.6 & $\ldots$ & 5.6 & $\ldots$ & $\ldots$ & $\cdots$ \\
\hline Foreign securities & 10.7 & $\cdots$ & 10.7 & $\ldots$ & $\ldots$ & $\cdots$ \\
\hline Sec. rec, under repo & 9.3 & $\ldots$ & 9.3 & $\ldots$ & $\cdots$ & $\cdots$ \\
\hline Repo receivables & ... & $\ldots$ & $\cdots$ & $\cdots$ & $\ldots$ & $\ldots$ \\
\hline Cash & 2.1 & 2.1 & $\ldots$ & 0.6 & 0.6 & $\ldots$ \\
\hline Loans (performing) & 54.9 & 54.9 & $\ldots$ & 12.0 & 12.0 & $\cdots$ \\
\hline Loans (past due) & 5.8 & 5.8 & $\ldots$ & $\cdots$ & $\ldots$ & $\ldots$ \\
\hline Other & 10.6 & 10.6 & $\ldots$ & 5.2 & 5.2 & $\ldots$ \\
\hline Totals & 100.0 & 73.4 & 26.6 & 19.2 & 17.8 & 1.4 \\
\hline
\end{tabular}

Source: Comisión Nacional Bancaria y de Valores, Boletín Estadístico de Banca Múltiple, March 1995.

Interbank borrowings were also classified as volatile. Banks' borrowings from other banks, about 42 percent of the September 1994 balances were borrowed by offshore branches of Mexican banks which were confidence-sensitive and volatile. The remainder (including some foreign currency-denominated liabilities) were obligations of domestic offices, but included borrowings from both domestic and foreign banks. Bonds are classified as mostly non-volatile although more information on maturity would permit a more accurate classification.

\section{Bank assets}

A simplified picture of Mexican bank assets just prior to the crisis is shown in Table 7. In classifying various items as liquid or illiquid, no special assumptions were made in the case of domestic and foreign securities, although the liquidity of domestic securities may be somewhat overstated.

Fixed income securities tend to have short maturities, and they are both saleable and can be repoed. Securities receivable under repo are securities that have been sold and are awaiting repurchase. There may be more of such securities, but Mexican accounting rules in effect at the time permitted limited netting against other transactions. Repo receivables arise from a purchase-and-resale transaction (a reverse repo), and the balance is viewed as liquid, given its short maturity. 
Cash includes cash in the vault, and correspondent and central bank accounts. Since these are vital in order to support intra-day teller transactions and interbank payments, any balance reductions must be made up quickly for the bank to keep its doors open. Ironically, cash is therefore not a liquid asset. Loans are considered illiquid even when current.

\section{Funding volatility ratio}

Calculating the funding volatility ratio for Mexico using the balance sheet data provided above shows a volatility ratio of 49.6 percent, suggesting that Mexican banks were relying on volatile sources of funds to finance almost half of their illiquid assets. This relatively high ratio suggests systemic vulnerability for the banking system. The ratio can also be calculated for the dollar sheet as well. In this case, Mexican banks in the aggregate fund 76.4 percent of their illiquid assets with volatile funding. As noted below, this ratio does not reveal the full exposure, particularly because off-balance sheet commitments are not mirrored in this simplified account. ${ }^{25}$

\section{Liquidity infrastructure}

Table 8 provides information on the liquidity infrastructure prevailing in 1994. Mexico's liquidity infrastructure relied strongly on the safety net for banks and for their creditors through both deposit insurance and central bank facilities. By contrast, the infrastructure supporting day-to-day liquidity management by banks had weaknesses.

For example, before the crisis, Mexican banks prepared their quarterly financial statements under guidelines issued by the National Banking and Securities Commission (CNBV), many of which were considerably less rigorous than International Accounting Standards (IAS). The treatment of asset quality was particularly distorted, leading to an overstating of the value of assets (showing a more favorable volatility ratio). Loans were slow to be downgraded, and even then, only the overdue payment themselves often needed to be classified as nonperforming. Interest continued to accrue on the remainder of the loan balance, and accruals could not be reversed. Provisions, meanwhile, ran directly to capital, without passing through the income statement. ${ }^{26}$

${ }^{25}$ For example, the impact of margin calls cannot be fully appreciated from the above balance sheet presentation.

${ }^{26}$ On December 29, 1995, CNBV issued Circular No. 1284 requiring that banks revise their accounting practices to conform more closely to IAS, beginning in 1997. 
Table 8: Mexico: Systemic Liquidity Infrastructure in 1994

\begin{tabular}{ll}
\hline Factor & $\begin{array}{l}\text { Supportive of an Effective } \\
\text { Liquidity Infrastructure? }\end{array}$ \\
\hline Day-to-day liquidity management & \\
1. Disclosure & No 0 \\
2. Prudential liquidity requirements & Yes 1 \\
3. Creditor rights & No 0 \\
5. Market depth, payments, monetary instruments & No 0.5 \\
6. Foreign exchange liquidity & No 0 \\
Safety net & \\
7. Credible deposit insurance & Yes 0.5 \\
8. Lender of last resort & Yes 1 \\
\multicolumn{1}{c}{ Total } & \\
&
\end{tabular}

A key prudential ratio (the "liquidity coefficient") required banks to maintain liquid foreign currency assets equal to 15 percent of their foreign currency liabilities. Mexico's general rules to protect creditors were known to be inefficient and ineffective. The 1943 law strongly favored the debtor, as well as the state and employees. ${ }^{27}$ Creditors found the process to be unworkable in the face of the many defaults of 1995 . In retrospect, the authorities view the depth of financial markets as not satisfactory as evidenced by the experience that during 1994, the government had to stop issuing one-year CETES and instead relied increasingly on dollar-indexed debt. On the other hand, central bank instruments appeared to be broadly supportive of the infrastructure and banks were not subject to reserve requirements at the time.

Foreign exchange liquidity management was flawed significantly. In particular, assets lent to domestic borrowers were not secured sufficiently by the borrowers' ability to generate foreign exchange earnings. In the face of dwindling foreign currency reserves and suddenly changing exchange rates, the fungibility of peso and foreign currency assets and liabilities broke down, leaving banks vulnerable to defaults on outstanding obligations.

\section{Safety net}

Mexico's system of deposit insurance in 1994 centered on the FOBAPROA, the Bank Fund for Savings Protection, overseen by board members appointed by the central bank, ministry of finance, and CNBV. It was created in 1990 and given the authority, but not the obligation, to "protect" bank creditors. The Fund could provide such protection by paying off creditors of defaulted banks or by extending preventive support, for instance, by lending to

\footnotetext{
${ }^{27}$ See also Lubrano (1996).
} 
troubled institutions as part of a rescue plan. ${ }^{28}$ Financing was provided by commercial bank contributions, supplemented by the FOBAPROA's ability to borrow from the central bank and government. The Fund's financial condition was not disclosed. Coverage was extended to virtually all instruments and all creditors, in any currency and without limit. Accrued interest was included implicitly.

FOBAPROA's guarantee seems to have been viewed differently within Mexico and abroad. Domestically, the widespread assumption was that the government would protect bank creditors. No one had lost money in a Mexican bank since the revolution. Bankers seemed to take confidence and, consequently, peso liquidity for granted and they did little to protect themselves against the remote risk of depositor flight. Externally, creditors were more skeptical. The central bank attributed this, in part, to the previous experience in 1982 where dollar deposits were converted into pesos at a rate fixed by the authorities leading to significant losses by depositors. ${ }^{29}$

\section{Crisis and response}

\section{Peso liquidity}

Peso deposits decreased. Overall bank accounts declined by eight percent in real terms during 1995. Some peso depositors moved into dollars and banks sought to raise peso funds elsewhere. Furthermore, the decline in value of some assets pledged as guarantees to secure dollar borrowings forced Mexican banks to take action. Banks had to raise pesodenominated funds to purchase dollars to meet margin calls. However, this additional source of pressure on liquidity is not (or is insufficiently) mirrored in the bank balance sheets, indicating an important shortcoming of available market data.

\section{Dollar liquidity}

Foreign holders of Mexican bank liabilities reacted to the turmoil culminating in the December 1994 devaluation. In January, exposures to Mexican banks were sharply reduced, by selling negotiable paper and by refusing to roll over maturing items. ${ }^{30}$ One large bank found that it could roll over only 10 percent of its maturing dollar CDs. Foreign currencydenominated deposits dropped by $\$ 3.5$ billion, or 23 percent of the total during the first

\footnotetext{
${ }^{28}$ Karaoglan and Lubrano (1995).

${ }^{29}$ The central bank had the authority and the willingness to act as a lender of last resort, as did the government-owned development banks, which had the ability to rediscount bank loans.
}

${ }^{30}$ Fourth quarter foreign exchange losses for the system as a whole were equal to 10 percent of total equity. See Karaoglan and Lubrano (1995). 
quarter of 1995 . The decline in dollar deposits was somewhat dampened by significant conversions from peso into dollar deposits.

The government produced a multi-pronged response. FOBRAPROA established a special window in January to provide short-term dollar loans to banks. Maturities were limited to 28 days, and the loans had to be collateralized with government securities, securities of NAFIN (the state-owned development bank), or equity securities of the recipient bank. The interest rate was punitive 25 percent, set in order to encourage banks to find substitute sources of fund quickly.

Banco de Mexico temporarily relaxed its 15 percent prudential liquidity coefficient, releasing banks to liquidate the dollar securities they had maintained against volatile dollar liabilities. Later, Banco de Mexico relaxed regulations that had limited bankers' ability to create a synthetic short dollar position with derivatives. This allowed the banks to substitute peso funding for dollar funding, using derivatives to cover the foreign exchange risk from their dollar loans. Seventeen banks took advantage of the FOBAPROA dollar window, accepting the punitive interest rate while searching for alternatives. On March 31, 1995, the banks had drawn down an aggregate of US $\$ 3.3$ billion. The facility peaked in April at about US $\$ 3.9$ billion. Banks also liquidated virtually all of the assets that had earlier fulfilled their liquidity coefficient requirement.

\section{B. Argentina 1994-95}

From a liquidity perspective, an important aspect of Argentina's banking environment in 1994 was its fragmentation. The banking sector comprised a large number of weak players, especially public, provincial, and niche-oriented private banks, and a few strong domestic and foreign banks. Bank depositors and creditors had experienced confiscation of accounts in the 1980 s and 1990s (through forced conversion into bonds), which weakened public confidence. Since 1991, Argentina had been committed to a rigorous monetary and fiscal regime, represented by a currency board. From a systemic liquidity perspective, this constrained the safety net because the Central Bank of the Republic of Argentina (BCRA) had only a limited ability to act as a lender of last resort. In addition, there was no deposit insurance scheme in place until April 1995 when the government created a limited selffunded deposit insurance program.

\section{Banking sector liquidity}

Table 9 shows a breakdown of the banking sector balance sheet by currency and by liquidity of assets and volatility of liabilities, respectively, as of 1994, shortly before the outbreak of the crisis in Mexico. For cash and reserves, Argentine reserve requirements were much higher than the need to cover intra-day payments liquidity, and BCRA's willingness to release these funds during the emergency suggested (ex post), that from a liquidity management standpoint, a significant portion of these balances could be considered liquid. 
Securities comprised short-maturity money market instruments and saleable or pledgeable securities.

Table 9. Argentina: Commercial Banks Balance Sheets (Percent of Total Assets) December 31, 1994

\begin{tabular}{|c|c|c|c|c|c|c|}
\hline \multirow[b]{2}{*}{ Assets: } & \multicolumn{3}{|c|}{ All Currencies } & \multicolumn{3}{|c|}{ FC-Denominated Only } \\
\hline & Total & Illiquid & Liquid & Total & Illiquid & Liquid \\
\hline Cash and reserves & 8 & 3 & 6 & 3 & 1 & 2 \\
\hline Securities & 5 & $\ldots$ & -5 & 3 & $\ldots$ & 3 \\
\hline Loans & 65 & 65 & $\ldots$ & 36 & 36 & $\ldots$ \\
\hline Other & 22 & 22 & $\ldots$ & 3 & 3 & $\ldots$ \\
\hline Total assets & 100 & 90 & 11 & 45 & 40 & $\mathbf{5}$ \\
\hline Liabilities: & Total & Stable & Volatile & Total & Stable & Volatile \\
\hline Deposits & 50 & 28 & 22 & 24 & 12 & 12 \\
\hline Wholesale liabilities & 11 & 1 & 10 & 11 & 1 & 10 \\
\hline Other & 19 & 19 & $\ldots$ & $\cdots$ & $\cdots$ & $\cdots$ \\
\hline Total liabilities & 80 & 48 & 32 & 35 & 13 & 22 \\
\hline Capital, subordinated debt & 16 & $\cdots$ & $\cdots$ & $\cdots$ & $\cdots$ & $\cdots$ \\
\hline
\end{tabular}

Source: Banco Central de la República Argentina, Boletín Estadístico.

On the liabilities side, the lack of deposit insurance suggested that many depositors would be confidence-sensitive. A significant portion of bank deposits ( 7 percent of total assets), however, came from the public sector. These are classified as stable. Wholesale liabilities are repurchase agreements, interbank liabilities, and bonds issued, which could largely be considered as volatile. Similarly, dollar assets and liabilities were classified, using an optimistic assumption that dollar deposits were about as volatile as domestic deposits.

\section{Funding volatility ratio}

The funding volatility ratio for Argentina on September 30,1994, allocating assets and liabilities as done above, was 24 percent, which indicates vulnerability to liquidity shocks. The dollar-only balance sheet at that time was also positive. It might be argued that in the case of Argentina, foreign exchange deposits were relatively more stable than domestic ones given Argentina's demonstrated commitment to currency convertibility and exchange rate stability. Nevertheless, the volatility ratio would have remained positive for foreign currency balance sheet items, indicating net exposure to confidence sensitive funds. 


\section{Liquidity infrastructure}

Argentina's liquidity infrastructure, summarized in Table 10 below, shows a fundamentally different approach than in Mexico. Whereas Mexico provided a weak environment for early detection and remediation of bank health (day-to-day liquidity infrastructure), Argentina's was relatively strong. With respect to the safety net elements (deposit insurance and lender of last resort), the situation was reversed.

Table 10. Argentina: Systemic Liquidity Infrastructure in 1994

Factor

Supportive of an Effective

Liquidity Infrastructure?

Day-to-day liquidity management

1. Disclosure

2. Prudential liquidity requirements

3. Creditor's rights

4. Market depth, instruments, etc.

6. Foreign exchange liquidity

$\begin{array}{ll}\text { Yes } & 1 \\ \text { No } & 0 \\ \text { Yes } & 1 \\ \text { Yes } & 1 \\ \text { Neutral } & 1\end{array}$

Safety net

7. Credible deposit insurance $\quad$ No 0

8. Lender of last resort $\quad$ No 0

Total

Regarding disclosure, Argentina complied broadly with international standards, although it was recognized that provisioning rules needed to be improved. Only two months before the impact of the Mexican crisis hit Argentina, BCRA had issued regulations that closed the gap, with implementation for periods ending December $31,1994{ }^{31}$ The rights of bank creditors appear to have been well established at the time of the crisis, in contrast to the situation a decade earlier. When a bank was liquidated, secured creditors and depositors were given priority over other creditors. Liquidation through court-supervised bankruptcy was a lengthy process, however, and in early 1995, it threatened to overwhelm the system. Part of the government's response was to put in place an enhanced set of laws allowing for a more streamlined liquidation process. A change in the charter of the central bank allowed for the separation between assets and liabilities of a bank, thus opening up the option to create "good bank-bad bank" type of restructuring plans.

Argentina did not have prudential liquidity requirements in place, although, as noted, relatively high reserve requirements compensated for this to some extent. As in Mexico, a

${ }^{31}$ For a summary of recent reforms in the financial sector, see, for example, IMF 1998 
major effort to upgrade the supervisory organization was underway when the crisis hit, although Argentina had progressed farther than Mexico. Nevertheless, fiscal constraints prevented the supervisors from acting as aggressively to close insolvent banks, which doubtless undermined the systemic confidence of institutional creditors.

Argentina had relatively well-developed financial markets in 1994 which may have cushioned the effects of the shock. Regarding central bank instruments, the BCRA imposed high reserve requirements on Argentine bank deposits-for example, 45 percent for dollar and peso demand deposit and savings accounts. This requirement constrained banks' liquidity management. On the other hand, it proved to be an important crisis-response tool for an otherwise constrained government.

On foreign exchange liquidity, about half of Argentina's bank assets and liabilities were dollar-denominated. The Convertibility Law of 1991 sought to provide assurance that foreign currency would be made available for repayment to creditors and that the dollar-peso parity would be maintained. Pre-crisis spreads of 2-3 percent between deposits denominated in the two currencies indicated that creditors had more confidence in the convertibility commitment than to the promise of continued exchange rate parity. These spreads widened to as much as 10 percent by March 1995, as depositors switched from pesos to dollars, while reducing their overall deposits at the same time. Eventually, the market regained confidence in the government's commitment, and the situation stabilized.

\section{Safety net}

Argentina had no deposit insurance at the time the Mexican crisis spread to Argentina. As a result, small depositors took flight along with institutional creditors. A limited, self-financed deposit insurance scheme (SEDESA) was established in April 1995, emphasizing small deposits. The currency board reduced the government's role in providing lender-of-last-resort support. BCRA's potential as a lender of last resort was similarly constrained (as well as by law), although it was able to marshal relatively significant resources for liquidity support using the available instruments

\section{Crisis and response}

In most respects, Argentina's liquidity infrastructure emphasized day-to-day liquidity management factors and early preventive action. The safety net was not formally in place. While this system was unbalanced, the emphasis on day-to-day management provided banks with strong incentives to create a robust system. In November 1994, Argentina's government bond market was weakened by the failure of a nonbank securities trading firm and by the subsequent tightening of credit to all securities dealers. A month later, the banking system was affected by the Mexican crisis. First to feel the impact were the one-branch wholesale banks, whose liquid assets fell in value just as their institutional sources of funds dried up. Within three months, there was a widespread withdrawal from the banking system-the total equivalent of $\$ 8$ billion, or 16 percent of total deposits. The impact on the weaker wholesale,

retail, and cooperative banks was much larger, however, since there was a shift of deposits to 
the larger domestic and foreign banks. Interest rates doubled for both peso and dollar deposits.

The government and BCRA responded to the crisis aggressively within the constraints of the 1991 Convertibility Law. BCRA decreased its high reserve requirements, releasing about $\$ 3$ billion, plus another $\$ 2$ billion through rediscounting and repo facilities, thus covering more than 60 percent of withdrawals. Emergency liquidity was assembled from public and private sources and made available to banks. In the aftermath of the Tequila crisis, the infrastructure was strengthened, including the establishment of a contingent liquidity facilities adding to the resilience of Argentina's banking system today (IMF 1998, p.61).

\section{LESSONS AND IMPLICATIONS}

The framework outlined for assessing the adequacy of arrangements for systemic liquidity is essentially that of auditing the infrastructural preconditions for deep and liquid money markets in the context of volatile funding arrangements by banks. The emphasis on a range of infrastructural preconditions makes the systemic approach presented in this paper particularly suitable for a broad range of countries, including industrial and emerging economies. While detailed microstructural issues affecting actual liquidity operations and market design remain, the framework is sufficiently robust to be diagnostic. Moreover, the approach can assist in identifying prescriptive reforms toward increasing resilience in the financial system and, thus, serve as a basis for systemic liquidity policy.

The benefits of deep and liquid money markets are multifaceted. Central banks have an interest because of their monetary policy responsibilities and their interest in financial sector stability. Deep markets facilitate the transmission of monetary policies; provide a basis for information and feedback indicators; and allow for intervention to achieve targets without undue price volatility. Public debt managers also have interest in liquid markets. Robust primary and secondary markets in government securities allow for conditions to minimize public debt service costs. Moreover, resulting yields in these markets can serve as benchmarks against which private debt markets can develop. For commercial banks, the principal benefit lies in their ability to perform portfolio adjustments in response to shocks.

With these shared interests in systemic liquidity come responsibilities to forge a framework for resilience. Bank management capabilities are key to an environment fostering robust markets. In this regard, mere compliance with a liquid assets ratio does not indicate liquidity soundness. The maturity profile of assets and liabilities, reliance on particular types of markets for funding and resulting volatility, are important considerations. An effective liquidity management policy should not only rely on having an adequate buffer of easily liquefied assets, but also require active participation by bank management in monitoring and forecasting liquidity positions.

In this regard, a volatility ratio can be used to assess individual banks' exposure to confidence sensitive funds. Prudence would dictate that banks should have more liquid assets 
than confidence-sensitive liabilities using a substance over form analysis of balance sheets to identify truly liquid assets and volatile liabilities. Beyond providing a legal and regulatory framework for confidence, involving transparent creditor rights, and information disclosure, monetary authorities need to invest in removing barriers to appropriate microstructures for market development. In this regard, issues of instrument design, prudential regulations, payment system design, and an appropriate balance between day-to-day and safety net arrangements are important.

The country reviews indicate mixed practice, suggesting a range on the scale of financial sector resilience to prospective liquidity shocks. Alternately, where arrangements are inadequate not only is monetary management made less effective, but also banks could be forced into inefficiencies, holding large stocks of non or low yielding liquid assets as a hedge, leading to higher intermediation spreads.

This framework also raises implications for the conduct of monetary operations. Countries using a reserve operation framework often include excess reserves as an indicator to guide intervention. To the extent that the level of excess reserves depends on the opportunity costs of such reserves, central banks can influence these balances through operations to change market rates. Transmission can however be blunted, if due to poor infrastructure the demand for excess reserves is sticky-as banks could risk illiquidity to invest outside of excess reserves. If intervention guides are set independent of an assessment of the robustness of the infrastructure, absorption could unnecessarily increase cost to the central bank for the same monetary effect. The state of infrastructure also impacts on interest rate operating frameworks through potential distortions to interbank markets. If banks are unsure of the conditions (due to rigidities or lack of information) for mobilizing funds, segmentation could occur, reducing the information content of the interbank rate as an operating target.

Finally, the framework provides an approach to an early warning indicator of potential stress and in this respect could be further developed towards a quantitative system of systemic liquidity analysis. Where financial systems overly rely on volatile funding sources to finance assets there is greater need for a robust infrastructure to fund potential shocks. Even where volatility ratios appear conservative, further analysis may be needed to ensure that markets really exist to realize the presumed liquidity. 


\section{Bibliography}

Baliño, Tomás J.T. and L. M. Zamalloa, 1997, Instruments of Monetary Management (Washington: International Monetary Fund).

Bank for International Settlements (BIS), 1999, Core Principles for Systemically Important Payment Systems. Report of the Task Force on Payment System Principles and Practices. (Basel: Bank for International Settlements).

-_, 1999, Market Liquidity: Research Findings and Selected Policy Implications (Report of a Study Group Established by the Committee on the Global Financial System (CGFS) of the Group of Ten Countries (Basel: BIS).

Bank of England, 1981, The Measurement of Liquidity (London: Bank of England, August).

Basel Committee, 1993, A Framework for Measuring and Managing Liquidity (Basel: BIS).

$\longrightarrow$, 1997, Core Principles for Effective Banking Supervision (Basel: BIS).

Borio, Claudio, 1997, Monetary Policy Operating Procedures in Industrial Countries (Basel: Bank for International Settlements).

Bundesbank, 1982, Central Bank Money Requirements of Banks and Liquidity Policy Measures of the Bundesbank Monthly Bulletin (Frankfurt/M: Deutsche Bundesbank).

Carstens, A. and M.J. Schwartz, 1998, "Capital Flows and the Financial Crisis in Mexico," Journal of Asian Economics (Vol.9, No.2, pp. 207-226)

Central Bank of Argentina, 1995, Bulletin of Monetary and Financial Affairs.

Claessens Stijn, S. Djankov, and Klapper Leora, 1999, Resolution of Corporate Distress: Evidence from East Asia's Financial Crisis (Washington: World Bank manuscript).

Dacey John, and Bazel-Horowitz Jackie, 1990, Liquidity Management: Recent Changes in Liquidity Management Practices at Commercial Banks (Federal Reserve Bank of New York).

Dattels Peter, 1995, "Microstructure of Government Securities Markets," IMF Working Paper 95/117 (Washington: International Monetary Fund).

Federal Reserve Bank of New York, 1990, Funding and liquidity: Recent Changes in Liquidity Management Practices at Commercial Banks and Securities Firms Staff Study (Federal Reserve Bank of New York). 
Group of 22, 1998, Report of the Working Group on Strengthening Financial Systems (October).

Garcia, Gillian G.H., 1999, "Deposit Insurance: A Survey of Actual and Best Practices," IMF Working Paper 99/54 (Washington: International Monetary Fund).

Gulde, Anne-Marie, 1995, "Liquid Asset Ratios-An Effective Policy Tool?" IMF Operational Paper (unpublished).

Hefferman, Shelagh., 1996, Modern Banking Theory and Practice.

International Monetary Fund (IMF), 1997, International Capital Markets (September).

—, (1998), Staff Country Report (Argentina), No. 98/38 (April).

Johnson, Omotunde E.G. et.al., 1998, Payment Systems, Monetary Policy, and the Role of the Central Bank (IMF).

Karaoglan, Roy A., and Lubrano Mike, 1994, Mexico's Banks After the December 1994 Devaluation-A Chronology of the Government's Response, Northwestern Journal of International Law Business, Vol. 16:24, p. 30).

Kochhar, Kalpana, 1996, “The Definition of Reserve Money: Does It Matter for Financial Programs?" IMF Paper on Policy Analysis and Assessment 96/9 (Washington: IMF).

Lamfalussy Report, 1990, Report of the Committee on Interbank Netting Schemes of the Central Bank of the Group of Ten Countries, November, (Basel: BIS).

La Porta, R., F. Lopez-De-Silanes, A. Shleifer, and R.W. Vishny, 1997, "Legal Determinants of External Finance," The Journal of Finance, Vol.52, No.3, July.

Lubrano Mike, 1996, "Practical Difficulties in Mexican Workouts and Bankruptcy," North American Corporate Lawyer, Vol. III, No. 3.

Mendes, Antonio, 1995, "A Brief Incursion into Bankruptcy and the Enforcement of Creditor's Rights," Northwestern Journal of International Law and Business , Vol. 16:107.

Muranaga, Jun and Tokiko Shimizu, 1999, "Market Microstructure and Market Liquidity" IMES Discussion Paper No. 99-E-14 (Tokyo: Bank of Japan)

Ohara, Maureen ,1995, Market Microstructure Theory (Cambridge, Massachusetts: Blackwell Publishers). 
Prestopino, Chris, 1994, "The Impact of Differential Reserve Requirements on Commercial Bank Liquidity and Portfolio Management" (University of Pennsylvania).

Reddy, Y.V. , 2000, "Developing Government Securities Market" Reserve Bank of India Bulletin (February)

Stigum, Marcia, L, 1983, Managing Assets and Liabilities: Strategies for Risk Control and Profit (Homewood, Illinois: D. Jones Irwin).

_, 1989, The Repo and Reverse Markets (Richard D. Irwin, Inc.).

Summers Bruce. J, 1978, "Managing Cash Assets: Operating Balances and Reserve Requirements," Economic Review (Federal Reserve Bank of Richmond).

De Villiers, J.U., 1996, "The liquidity of financial assets", South African Journal of Economics (South Africa: 64:1-23, June).

White, Michelle J., 1993, "The Costs of Corporate Bankruptcy; a U.S.-European Comparison," University of Michigan Institute for Public Policy, Discussion Paper No. 346 (August) 